\title{
Učitel náboženství - misionář a evangelizátor, ale i profesionál a expert. Především však křestáan prožívající hluboký niterný vztah k Bohu skrze Krista Ludmila Muchová
}

\author{
Úvod
}

Zájem o osobnost učitele náboženství v české odborné literatuře je v posledních letech často zaměřen na konkrétní osobnosti významných věřících pedagogů nebo katechetů. ${ }^{1} \mathrm{~V}$ pozadí zůstává otázka, jaké charakteristiky lze nalézt u osobností současných českých učitelů náboženství, 28 let od doby, kdy byla výuka tohoto předmětu znovu obnovena na českých školách. Položila jsem ji v souvislosti se zájmem mých kolegů - pedagogů volného času - o charakteristiky osobností pedagogů volného času na katedře pedagogiky TF JU, který mě upozornil na výzkumný deficit ve vztahu k českým učitelům náboženství.

Moje výzkumná otázka zní: Jaké podstatné charakteristiky lze nalézt v osobnosti učitele náboženství v současné době v naší zemi? Při hledání odpovědi chci zvolit teoretický rámec opírající se o normativní pohled i o empirický pohled dvou německých autorů doplněný o dva výzkumy menšího rozsahu s podobným tématem v České republice. Na jejich analýzu naváži popisem kvalitativně orientované výzkumné sondy, kterou jsem provedla v jarních měsících roku 2017 v rámci římskokatolické církve (v českobudějovické diecézi) metodou analýzy a interpretace jednoho rozhovoru v ohniskové skupině učitelů náboženství. Její závěry posléze srovnám s výsledky empirických výzkumů citovaných v kapitole vymezující teoretický rámec práce.

\section{Teoretický rámec pro kvalitativní sondu do charakteristiky osobnosti českého učitele náboženství a jeho role ve společnosti a církvi}

Normativní pohled především na osobnost katechety představuje $\mathrm{v}$ českém prostředí autorská dvojice Dřímal, Alberich, kteří odkazují na situaci, ve které je role katechety v církvi směšována s rolí učitele náboženství ve škole. Podle nich nese katecheta (a do určité míry analogicky i učitel náboženství) za své působení zodpovědnost na základní rovině (střední rovina odpovědnosti př́ísluší vikariátním katechetickým a pedagogickým centrům, vyšší rovina vedoucím katechetických center na úrovni diecézí, kněžím a biskupům a vyučujícím zodpovědným za vzdělávání a další vzdělávání katechetů a učitelů náboženství). Ve vztahu k osobnosti katechetů hovoří o tzv. „kate-

1 Srov. např. Ludvík DŘíMAL, František Tomášek jako katecheta dětí a mládeže, Olomouc: Matice cyrilometodějská, 2002 nebo Marie ZIMMERMANOVÁ, ThDr. Josef Hronek jako katechetik a pedagog, Praha: Karolinum, 2012 nebo Ludmila MUCHOVÁ, Solidarita otřesených - životní cesta a odkaz P. Pittra naší době, Theologia vitae 2/2015. 
chetické kompetenci“. Ta se podle nich projevuje ve třech dimenzích: v dimenzi bytí, vztahující se ke zralosti jak v rovině přirozené, tak v rovině víry. Přirozená rovina předpokládá emocionální vyrovnanost, projevující se např. ve schopnosti přijmout kritiku nebo jednotu myšlení, slov a činů, umění vést dialog apod. Zralost $\mathrm{v}$ rovině víry se projevuje jednak jejich učením, jednak svědectvím vlastního života, a to nejen ve vztahu $\mathrm{k}$ samotné víre, ale také $\mathrm{k}$ církvi. Druhou dimenzí je dimenze vědění, která spočívá jednak ve znalostech nabytých $\mathrm{v}$ oblastech dílčích teologických disciplín, jednak v citlivosti vůči pastoračním potřebám církve v kontextu společnosti, v níž žijí a pracují. Součástí této dimenze je i dimenze zkušenostní, která předpokládá zkušenost $\mathrm{v}$ oblasti zprostředkování znalostí jak vzhledem např̀ k biblickým obsahům a tradici církve, tak vzhledem $\mathrm{k}$ současné společenské situaci. Třetí dimenzí je dimenze dovedností, která zahrnuje př̌edevším profesionalitu, která je předpokladem výchovného a komunikačního působení katechety. Autoři Dřímal a Alberich zdůrazňují především dovednosti, které podporují rozvíjení dobrých vzájemných vztahů ve skupinách, označují je souhrnným názvem „,animace“.2 Tento jejich stručný popis katechetické kompetence má spiše normativní charakter, odvolává se na V̌̌eobecné direktorium pro katechizaci. Autoři se nevěnují výzkumu reálných podmínek, ve kterých se výuka náboženství a katecheze v českých zemích odehrává. Z jejich stručného rozboru plyne, že povolání katechety (analogicky i učitele náboženství) by mělo propojovat vysoce kvalitní osobnostní vyspělost, křestanskou hloubku a profesionalitu.

Jak této obecné představě odpovídá skutečná realita? Z výsledků kvantitativního průzkumu, který jsem v roce 1999 provedla v českobudějovické diecézi, uvádím těchto několik výsledků: Pouze $25 \%$ vyučujících mělo vysokoškolské teologické vzdělání, 22 \% absolvovalo jinou než teologickou vysokou školu. Vysokoškoláci vykazovali srovnatelně malý počet hodin výuky jako středoškoláci. Prostředí školy vnímali vyučující náboženství v 75 \% jako mírně až velmi přátelské, ale nedělali si iluze, že by ho svou př́tomností nějak ovlivnili. Na výuku se převážně těšili, radost jim přinášel zejména kontakt s dětmi. Obavami z výsledku hodiny trpělo pouze $17 \%$ učitelů, nejistotou $\mathrm{z}$ vlastních schopností $16 \%$. Jihočeské učitelky a učitelé náboženství byly také velmi zbožné. Často naplňovali cestu do školy modlitbou a i sílu pro svou práci hledali nejčastěji v osobní modlitbě (31\%), dále ve svátostném životě (23\%), ve společenství s dalšími vyučujícími (22\%), méně často v životě se svou farností (15\%). Svou osobní spiritualitu rozvíjeli v úzkém kontaktu s církví - prostřednictvím duchovních obnov nabízených církví. Daleko méně ochotni byli účastnit se aktivit nabízejících jim další vzdělávání (pouze 15 \% bylo připraveno kombinovanou formou studia absolvovat vysokou školu, tentýž počet byl ochoten účastnit se pravidelných doškolovacích kursů $\mathrm{v}$ diecézním městě). Výsledky kvantitativního výzkumu svědčily o tom, že zde byla narušena rovnováha mezi profesionální a spirituální kompetencí jihočeských učitelů a učitelek náboženství. ${ }^{3}$ O 7 let později (v roce 2006) jsme provedli výzkum týkající se náboženské výuky na území celé ČR v římskokatolické církvi i v jiných denominacích. Kromě jiného byl položen důraz na charakteristiku vlastní víry učitelů a učitelek náboženství, na jejich vztah k instituci církve, školy a ke světonázorově pluralitní společnosti. ${ }^{4}$ Přibližně polovina respondentů splňovala kvalifikační podmínku pro výuku náboženství - vysokoškolskou kvalifikaci, tedy obdobný počet, jako ve výzkumu v jižních Čechách. Směrem $\mathrm{k}$ charakteristice vlastní víry učitelů a učitelek náboženství se naprostá většina přihlásila $\mathrm{k}$ tzv. ortodoxnímu postoji, tj. $\mathrm{k}$ přesvědčení o doslovném chápání

2 Srov. Emilio ALBERICH - Ludvík DŘíMAL, Katechetika, Praha: Portál, 2008, s. 189-193.

3 Srov. Ludmila MUCHOVÁ, Náboženská edukace v současné společnosti, Habilitační práce. Ružomberok: Pedagogická fakulta Katolíckej univerzity, 2007, s. 167.

4 Srov. Ludmila MUCHOVÁ - František ŠTĚCH, Rozpaky nad pluralitou v české náboženské výchově?, Studia theologica 2/2008, s. $72-87$. 
textů Bible při současné víře v Boha. Zároveň se ale téměř polovina hlásí k tzv. „druhé naivitě“, tedy $\mathrm{k}$ postoji symbolického chápání významu biblických textů při současné víře v Boha. Téměř polovina však s tímto postojem nesouhlasí. Vztah k biblickým textům bez současné víry v Boha $\mathrm{v}$ jakékoliv podobě respondenti odmítli. Jejich postoje jsou tedy značně polarizované, část směřuje $\mathrm{k}$ víre vycházející $\mathrm{z}$ doslovné interpretace Bible, která je náchylná $\mathrm{k}$ fundamentalismu, část opírá svou víru o biblické texty, kterým rozumí v jejich symbolické formě. Ve vztahu ke světonázorově pluralitní společnosti se čeští učitelé náboženství vyslovili pro výuku zaměřenou katecheticky, tedy k posilování křestanské identity žáků uvnitř vlastního náboženství. Pokud považovali světonázorovou a náboženskou pluralitu za obohacující, měli tendenci reagovat na ni ve výuce tím, že vzhledem k ní podají žákům pouze informace, bez možnosti skutečného setkání se s touto realitou a dialogu s ní. Ve vztahu k církvi potom respondenti byli převážně jejími aktivními členy. Ve vztahu k instituci, která garantuje výuku (z části církev, z části škola), uvedla téměř jedna pětina, že prožívá stres častěji než zřídka, 20 \% referovalo o častějším pocitu vyhoření. Téměř $60 \%$ si stěžovalo na malou prestiž svého předmětu a s didaktickými materiály, za které je odpovědná církev, projevilo spokojenost pouze 52,3 \% respondentů.

Z obou výzkumů lze vyvodit závěr, že čeští učitelé a učitelky náboženství vnímají svou profesionalitu, ačkoliv často nesplňují profesionální požadavky na vzdělání. Vnímají i svou osobní religiozitu a dokážou ji nějak vyjádřit i v životě v církvi. Nejsou si však příliš jisti okolní světonázorově a nábožensky pluralitní společností. Mají tendenci dávat samotné výuce spíše katechizační formu bud' bez vztahu ke světonázorové pluralitě, nebo pouze s podáním objektivních informací o jiných náboženstvích... Poněkud nejistí ve své profesionalitě, poněkud opomíjeni školami, ve kterých vyučují, poněkud uzavírající výuku před okolní společností, ale pevně zakořeněni ve své církvi.

V některých sousedních zemích se nesetkáme s obdobným postavením předmětu náboženství, jako je tomu u nás. Rozdíl spočívá především v množství žáků a studentů, kteří se k výuce předmětu hlásí, a to i v př́ípadě, že předmět nemá povinný charakter. ${ }^{5} S$ naší situací však mají společné to, že výuka náboženství má konfesní charakter a za její kvalitu a průběh odpovídá společně se státem také církev. S touto skutečností je potom spojena i teoretická reflexe role učitelů náboženství ve společnosti a v církvi v těchto zemích (např. Polsko, Rakousko, Německo, ale i Slovensko). Ve Velké Británii se liší předměty týkající se náboženství i svým zacílením a obsahy, takže s nimi nemá smysl srovnávat teoretické reflexe týkající se osobnosti a role učitele náboženství.

Velké množství odborných článků a studií na toto téma můžeme najít v německy hovořících zemích. I přes výše zmíněnou odlišnost v počtech žáků absolvujících předmět náboženství zde v posledních letech přibývají otázky kladoucí své těžiště na osobnost a roli učitelů náboženství vzhledem ke zrychlujícím se změnám v evropské společnosti a vzhledem ke snižujícímu se zájmu o náboženství v ní. Vzhledem k rozsahu tamních studií a výzkumů vybírám pouze pohledy dvou renomovaných náboženských pedagogů v těchto regionech. ${ }^{6}$

Norbert Mette rozlišuje dvě základní kategorie vlivů, které na učitele náboženství působí. První jsou jeho individuální postoje, mezi kterými jmenuje především profesní habitus a osobní religio-

5 Více srov. (C) Jana SKOKOVÁ, Náboženství jako součást školní edukace v různých zemích Evropy (on-line). Diplomová práce, TF JU v Českých Budějovicích, 2012. Dostupné na http://www.vyzkum-mladez.cz/zprava/1476795788.pdf, citováno dne 5. 6. 2017.

6 Ze studií, pocházejících jak z katolického, tak reformačního rámce náboženské pedagogiky posledních 10 let, lze jmenovat autority jako jsou Hans Mendl (Passau), Martin Rothangel (Wien), Hans Georg Ziebertz (Würzburg) a další. Vzhledem k rozsahu tohoto článku jsem zvolila pouze dva autory, kteří zasazují svoje vlastní výzkumy do historizujícího rámce. Dlužno podotknout, že i aktuální literatura posledních 10 let komentuje kategorie obdobné těm, které tito dva autoři ve svých výzkumech popsali již před více než 10 roky.

7 Srov. Norbert METTE, Zum Beruf und Selbstverständnis von Religionslehrern und -lehrerinnen im Kontext aktueller Entwicklungen in Gesellschaft und Schule sowie Religion und Kirche, Christlich pädagogische Bletter 3/2004, s. 134-136. 
zitu, druhou jsou různé sociální vlivy, např. instituce školy a její kultura, společnost jako taková atd. Mette upozorňuje, že všechny tyto okolnosti rozhodujícím způsobem ovlivňují způsob náboženské výuky konkrétního učitele, vzájemně se však podmiňují a vyvijejí se spolu s množstvím let učitelovy praxe, takže je velmi obtížné je zkoumat. Mette považuje za podstatné tř̌i kategorie: vliv školy, vliv vztahu učitele $\mathrm{k}$ církvi a jeho vlastní religiozitu, která souvisí s charakterem jeho osobnosti. Mette konstatuje, že v prostředí školy postupují němečtí učitelé náboženství nejčastěji $\mathrm{v}$ souladu s nejnovějšími didaktickými zásadami, které obracejí pozornost $\mathrm{k}$ žákům. Současně volí metody práce, které vycházejí $\mathrm{z}$ křestanských hodnot, takže směřují k rozvíjení hlubokého lidství žáků ve vztahu $\mathrm{k}$ transcendentní skutečnosti - $\mathrm{k}$ Bohu, vycházejí důsledně z každodenních zkušeností žáků, reflektují je s nimi ve světle biblického poselství, pomáhají jim objevit a kultivovat jejich vlastní religiozitu, rozhodovat se pro vlastní existenciální postoje vůči transcendenci, vystupují jako obhájci žákovských potřeb. Proto začíná v posledních průzkumech patřit předmět náboženství $\mathrm{k}$ oblíbeným a učitelé náboženství mezi žáky též $\mathrm{k}$ nejoblíbenějším. Současně jsou však vzhledem $k$ mezinárodním srovnávacím výzkumům PISA konfrontováni s pokusy o reformu školství, která je zaměřená na profesní přípravu žáků. Učitelé náboženství v německy mluvících zemích žijí pod tlakem, aby ve svých kurikulárních dokumentech jasně formulovali, jaké specifické vědomosti a dovednosti žáci v jejich předmětu vzhledem $\mathrm{k}$ budoucí profesi získají, vymezili vědomostní standardy apod., a to vše pod velkým tlakem na efektivitu výuky. To se podle Metteho může stát pro učitele náboženství výzvou, aby jasně formulovali specifický „standard“ vedoucí nejen $\mathrm{k}$ poctivému př́stupu $\mathrm{k}$ budoucí profesi žáků, ale zejména ke společnému životu s lidmi různých životních orientací jako odpovědných subjektů, kteří disponují jasnou humánní představou o budoucím světě. Tím se však ocitají v určitém napětí mezi výchovným a úzce vzdělávacím úkolem. $S$ podobným napětím by se mohli setkávat učitelé náboženství v naší zemi $\mathrm{v}$ souvislosti se školskou reformou z roku 2004. Profesionální aspekt rozměru práce učitele náboženství tedy v sobě nese napětí mezi směřováním školských systémů EU ke stále propracovanější profesní orientaci žáků a křestanským pohledem na hodnotu života jako takového, která plyne ze stvořenosti člověka a světa Bohem, nikoliv $z$ jeho úspěchu či neúspěchu na trhu práce.

Ve vztahu k církvi upozorňuje Mette na to, že učitel náboženství nepředstavuje jednoduše prodlouženou ruku církve v prostoru školy, ve škole nerealizuje církevní katechezi. Důvodem je vzdálenost mezi prostorem školy a církve, která byla nastolena evropským vývojem v posledních staletích. Zatímco tedy v prostoru církve jde především o rozvíjení křestanských postojů dětí a mladých lidí ve spojení $s$ životem $z$ víry celého věřícího společenství (např. farnosti), ve škole jde především o rozvíjení křestanských postojů dětí ve spojení s porozuměním křestanství a náboženství, které žákům umožní zaujímat k náboženství svůj vlastní postoj na základě schopnosti ho posoudit. Úkolem učitelů náboženství ve školách je pomoci žákủm, aby vůbec poznali obsahy křestanské víry a porozuměli jazyku, kterým jsou v rámci křestanství vyjadřovány (tzv. náboženská alfabetizace). Učitelé náboženství však často narážejí na to, že takto popsaný přístup k prostř̌edí školy nenachází důvěru u oficiálních církevních představitelů. Na druhou stranu se stávají nejbližším terčem kritiky jak žáků, tak kolegů - učitelů v situacích, kdy je konfrontují s jednáním církve, které považují za špatné nebo nepochopitelné ( $\mathrm{v}$ českých poměrech by se mohlo jednat o restituce církevního majetku, aféry homosexuálních kněží apod.). Německé výzkumy ukazují na to, že samotní učitelé náboženství mají ke své církvi často velmi angažovaný, a sice kritický, ale loajální postoj. Prožívají tak napětí mezi svým vlastním postojem a očekáváním vůči církvi (důvěra, podpora), ale dostává se jim spíše nedůvěry a předsudečně zabarvené kritiky. Navíc bývají učitelé náboženství často svými kolegy i žáky automaticky považováni za experty v otázkách 
světových náboženství, setkávají se v této souvislosti i s řadou předsudků. Ne vždy se však cítí být dostatečně vzděláni na to, aby mohli být nápomocní skutečně odbornými znalostmi, protože je nezískali v rámci př́pravného studia. I toto napětí mezi očekáváním expertnosti v obecných náboženských otázkách a vlastní připraveností lze často vnímat v rozhovorech s českými učiteli náboženství.

V třetí kategorii - vlastní křestanské postoje učitelů náboženství - se Mette odvolává na vlastní kvalitativně orientovaný výzkum prováděný mezi učiteli všech vzdělávacích stupňů, který ukázal na to, že učitelé náboženství mají ve srovnání s učiteli jiných předmětů pro svou práci jinou motivaci a prožívají svůj předmět jako výzvu v poněkud jiném smyslu. ${ }^{8} \mathrm{~V}$ tomto předmětu nemohou zastávat neutrální pozici. Děti se jich na jejich vztah k Bohu, ke křestanství a k církvi ptají, očekávají jejich autentičnost ve vztahu, který projevují ke křestanské víre. Učitelé se mohou cítit tímto třeba i nevysloveným požadavkem přetíženi. Neumí rozlišit mezi svou autenticky prožívanou křestanskou vírou, v níž se mohou dostat i do krizí, a situací, v níž tuto svou víru s odstupem reflektují a teprve takto promyšlenou představují svým žákům. Přitom se nesmí posunout do role nezúčastněných pozorovatelů, kteří zaujímají vůči náboženství odstup. Osobní historie jejich vztahu $\mathrm{k}$ Bohu je důležitou součástí výuky. Podle Metteho jde o to, aby vedle promýšlení vlastní víry, které by měl praktikovat každý věrící křestan, uměl učitel náboženství ještě „reflektovat tuto reflektovanou víru“, aby ji dokázal didakticky využít. Didaktickým využitím míní Mette zacílení na vytvoření rovnovážného vztahu mezi vlastní reflexí víry a reflexí, kterou se snaží umožnit svým žákům ve vztahu $\mathrm{k}$ jejich viŕe. To je cíl, o který nebylo nutno usilovat v dobách, kdy křestanství představovalo obecný postoj členů společnosti k životu. $V$ nábožensky pluralitní společnosti a ve státě světonázorově neutrálním je to však důležitá služba žákům. ${ }^{9}$

Mette tedy vnímá pozici učitele náboženství na veřejné škole jako pozici obsahující v sobě řadu napětí:

- ve vztahu ke vzdělávacímu systému napětí mezi cílem vzdělávat $\mathrm{k}$ hlubšímu prožívání lidství žáků a úzkým požadavkem připravit je odpovídajícím způsobem na budoucí profesi;

- ve vztahu ke škole, kde působí, napětí mezi očekáváním kolegů a žáků, že jsou experty na otázky spojené se světovými náboženstvími, a vlastním nedokonalým vzděláním v tomto směru;

- ve vztahu k církvi napětí mezi orientací na rozvoj porozumění křestanství a vlastní rozhodnutí k zaujetí postoje u žáků a očekáváním církve, že budou zprostř̌edkovávat žákům především určité kvantum konfesních znalostí;

- ve vztahu k vlastní víře napětí mezi svou vlastní žitou religiozitou a reflektujícím odstupem vůči ní tak, aby se mohla stát součástí obsahů výuky náboženství.

Učitelé náboženství tedy podle Metteho studie prožívají svou profesionalitu jako napětí ve vztahu k cílům školského vzdělávání a ve vztahu ke své roli experta. Roli svědka víry a misionáře od nich očekává církev, i tento rozměr své role mohou cítit jako napětí. Z Metteho výkladu tedy plyne, že učitel náboženství by měl být vzdělaný profesionál - jak v oblasti církevního učení, tak v širších náboženských oblastech - a i ve vztahu ke schopnosti reflektovat svou vlastní odbornost. To samozřejmě musí platit i pro české učitele náboženství, pouze s tím rozdílem, že předmět náboženství bud' na mnoha školách zcela chybí (z důvodu malého počtu přihlášených žáků), nebo

8 Mette cituje odkaz na výzkum publikovaný v knize Saskia HÜTTE - Norbert METTE, (u. a.) Religion im Klassenverband unterrichten. Lehrerinnen berichten von ihren Erfahrungen, Münster: LIT Verlag, 2003.

9 Srov. METTE, Zum Beruf..., s. 134-138. 
je vyučován v odpoledních hodinách, kdy již ostatní učitelé školní budovu opouštějí, takže čeští učitelé náboženství trpí často spiše marginalizovaným postavením svého předmětu v rámci školy. Což ovšem nevylučuje, že jim jejich kolegové - učitelé otázky týkající se křestanství a církve vůbec nepoloží. Nějaký kontakt nastává např̀. s třídním učitelem v učebně, ve které probíhá jejich výuka, mají také občasný kontakt s vedením školy apod.

F. Schweitzer ${ }^{10}$ považuje i v německých zemích označení učitelství náboženství jako profesi za poněkud pochybné, a to zejména proto, že samotní učitelé náboženství jsou většinou zároveň nositeli jinak orientovaných nábožensko-vzdělávacích aktivit - v roli učitelů náboženství vystupují kněží ( $v$ evangelické církvi, k níž se F. Schweitzer hlásí, faráři nebo farářky), kteří současně zodpovídají ještě za další pastorační služby. A rovněž tzv. laičtí učitelé a učitelky náboženství vedle výuky ve škole obstarávají i katechezi ve farnosti, kde pracují i s jinými věkovými kategoriemi: s dospělými, seniory, nemocnými apod. Navíc ne vždy pobírají za farní aktivity mzdu. Schweitzer tedy upozorňuje, že ke skutečné profesní roli chybí učitelům náboženství v Německu především jedinečnost specifického odborného zaměření, které by rozvíjeli v rámci jediné profese, která by jako celek byla zdrojem jejich obživy. Platí-li to pro německé země, platí to dvojnásob v podmínkách země české, v nichž se obecně učitelé náboženství pohybují.

Schweitzer zařazuje otázky spojené s výzkumy napětí plynoucí z role učitele náboženství jako učitele - profesionála do 70. let minulého století. Zkoumána byla především očekávání žákio. Z výzkumů vyplynulo, že děti a mladí lidé projevují o výuku náboženství zájem v případě, že je vztažena k problémům $\mathrm{v}$ jejich osobních životech, daleko méně zájmu projevovali o církevní učení jako takové a o církevní tradici. Jako významný se projevil vztah učitelů náboženství $\mathrm{k}$ učebním osnovám. Zejména jejich prostřednictvím vnímali učitelé náboženství svůj předmět jako legitimní předmět vyučovací, díky němuž cítili odpovědnost za výuku směrem $\mathrm{k}$ vedení školy, inspekci, právnímu postavení předmětu apod. Výzkumy též ukázaly překvapivě vysoká hodnocení úrovně výuky ze strany rodičů žákư, kteří současně očekávali významný př́nos výuky náboženství k hodnotové výchově svých dětí, co do vztahu ke zprostředkování náboženských obsahů však měly různé skupiny rodičů zcela různá očekávání podle toho, jak blízko či daleko se oni sami cítili být vůči církvi. Jako další důležitá kategorie se v různých výzkumech ukázala být kategorie očekávání ze strany státu. Zatímco z 19. století zde přetrvávaly tendence očekávat, že náboženská výuka podpoří hodnotovou výchovu žáků vedoucí $\mathrm{k}$ loajalitě vǔči státnímu zřízení, $\mathrm{v}$ posledních desetiletích přibývá jako důležitá kategorie př́spěvek $\mathrm{k}$ hodnotové výchově orientované na spolužití občanů v multikulturní a multináboženské společnosti. Církve svá očekávání vưči výuce náboženství na státních školách popisují ve svých dokumentech. Pro katolické učitele náboženství zde platí dokument Všeobecné direktorium pro katechizaci, $\mathrm{z}$ něhož jasně plyne rozdílnost cílů ve výuce náboženství oproti církevní katechezi, platí však, že pro výuku náboženství potřebuje učitel náboženství pověření církve, která si tak zajištuje, že učitelé náboženství budou její aktivní členové. Poslední důležitou kategorií je vliv náboženské pedagogiky jako vědy, která bývá v podezření, že posouvá svá očekávání kladená na výuku náboženství směrem od konfesních obsahů k obecné osobnostní výchově. V reakci na to vyvstává požadavek na formulaci přesněji vymezených kompetencí a standardů pro náboženskou výuku. Tento trend zaznamenáváme i v české katolické církvi.

Od 80. let minulého století získaly podle Schweitzera na důležitosti výzkumy spojené s otázkami vztahu mezi učitelskou rolí učitele náboženství a jeho osobní životní historií a náboženskou

10 Srov. Friedrich SCHWEITZER, Religionspädagogik. Lehrbuch PraktischeTheologie. Band 1, München: Gütersloher Verlagshaus, 2006, s. $185-196$. 
orientací, tedy s jeho religiozitou. Nešlo však o tvorbu ideálního obrazu učitele náboženství (jak to naznačili např. autoři Dř́mal, Alberich ve vztahu k osobnosti katechety), který se prokazuje i v jeho osobním životě, ale o výzkumy, které se věnovaly vztahu mezi jeho individuální životní historií a jeho možnostmi být dobrým učitelem náboženství. Šlo o takové životní události, jako jsou např. psychická zranění nebo vlastní hranice. S tím vším byl spojen nový termín „profesní identita učitele náboženstvi'. Schweitzer shrnuje velké množství jak kvantitativních, tak kvalitativních výzkumných šetření a specifikuje následující tendence, které z nich vyplynuly:

Kvantitativní a kvalitativní výzkumy profesní spokojenosti učiteli̛ náboženství ukázaly jak na vnější faktory (kladné - akceptace předmětu vedením škol a kolegy, ale i negativní - např. chybějící náboženská rodinná socializace žáků ve výuce), tak na vnitřní faktory spočívající v postojích samotných učitelů vůči náboženství a vůči výuce předmětu.

Kvalitativní výzkumy (především př́padové studie) přispěly poznatkem o významu osobní biografie jako předpokladu pro profesní identitu učitele náboženství. Ukázaly jednak na důležitost prŕslušnosti učitele $\mathrm{k}$ určité věkové kohortě a tím pádem zasaženost společenskými událostmi (v českých poměrech bychom je mohli přirovnat $\mathrm{k}$ zážitku 2. světové války, pronásledování církve za socialismu, Sametové revoluce apod.), tak na individuálních zkušenostech a zážitcích (např. setkání s konkrétním učitelem náboženství v dětství, s knězem, který motivoval mladé lidi k práci pro církev apod.).

Žité a vyučované náboženství jako dvě kategorie popsaly výzkumy, které ukázaly na rozlišování mezi religiozitou, kterou učitelé náboženství žijí a uskutečňují ve svém osobním životě, která však není beze zbytku zprostředkovatelná žákům. Učitel potřebuje za pomoci profesního a dalšího vzdělávání získat odstup od svých vlastních životních zkušeností, které ovlivnily jeho náboženské přesvědčení, a transformovat je do podoby zprostředkovatelné žákům až ve chvíli, kdy promyslí jejich vztah k obsahům a cílům výuky.

Postoj vůči církvi je kategorie, která byla zejména v německy mluvících oblastech zdrojem obav z př́lišsného vzdálení se učitelů náboženství církvi. $\mathrm{V}$ katolickém prostředí se však ukázalo, že mezi učiteli přibývá těch, kteří se současně živě angažují také v životě církve. $\mathrm{V}$ českém prostředí bývá tato kategorie „ošetřena předem“ mechanismem žádání o kanonickou misi, ve kterém stvrzuje aktivní vztah $\mathrm{k}$ církvi učitele náboženství kněz.

Reflexe cílů výuky samotnými učiteli podle těchto výzkumů neodpovídá vždy zcela jednoznačně jejich určenosti nábožensko-didaktickými teoriemi vtělenými do kurikulárních dokumentů. Podléhá ještě jiným faktorům - např. nejistota ve formulaci cílů ve výzkumech v zemích bývalého východního Německa může ukazovat na „didaktickou nejistotu“ učitelů náboženství, která souvisí se vztahem mezi církví, školou a samotným křestanstvím.

Schweitzer referuje krátce i o výzkumech, které se nevěnovaly otázce, jak sami sebe vnímají samotní učitelé náboženství, ale otázce, co od nich očekává církev a samotní žáci. Cituje výzkumy, které ukázaly ze strany žáků na potřebu větší osobní pozornosti a sebeprezentaci učitelů náboženství jako vzorů pro dětský a mládežnický život, žáci očekávali od předmětu, aby v něm mohli být aktivní, aby byl plný dynamiky a změn, orientovaný na jejich reálný život. Schweitzer jako výsledný poznatek $\mathrm{z}$ výzkumů $\mathrm{v} 80$. letech 20 . století vyvozuje závěr, že profesní identita učitele náboženství souvisí jednak s vývojem jeho náboženského přesvědčení v jeho konkrétním životě, jednak se znalostí a porozuměním vưči současnému životu dětí a mladých lidí.

$\mathrm{V}$ posledních letech došlo podle Schweitzera k výměně pojmu „profesní identita“ učitele náboženství za pojem „profesní kompetence“ učitele náboženství. Souvisí s tlakem, který na školní výuku obecně vyvíjejí mezinárodní srovnávací testy školních výkonů (PISA apod.). Ve spojitosti 
s nimi byly vyvinuty nejprve kompetence týkající se klíčových znalostí a dovedností žáků, od nich potom byly odvozeny kompetence učitelů, kteří k nim mají žáky dovést. A učitelům má získání těchto kompetencí zprostředkovat systém jejich vzdělávání. Ke kontrole žákovských kompetencí slouží systém standardizovaných úloh, které žáci řeší, a tím prokazují nabytí kompetencí. Tomuto trendu se přizpůsobilo i české národní kurikulum (viz Rámcový vzdělávací program pro základní vzdělávání ${ }^{11}$ ) v jeho logice postupují i doporučení katolických diecézních katechetických center $\mathrm{k}$ tvorbě školních vzdělávacích programů jako příloh či přímých součástí školních vzdělávacích programů. Schweitzer referuje o kritice, kterou podrobují tento systém orientovaný jednostranně na výkony žáků někteří pedagogové. V našich poměrech můžeme odkázat např. na Skalkovou. ${ }^{12}$ Přesto se dějí pokusy i v oblasti náboženské výuky formulovat specifické žákovské kompetence. Stalo se tak například v návrhu českého církevního dokumentu metodicky upravujícímu výuku náboženství na českých církevních školách v r. 2016, který ovšem nebyl přijat Českou biskupskou konferencí.

Schweitzer tedy vidí s odkazem na příslušné výzkumy ve druhé polovině 20. a na začátku 21. století vývoj profesní identity učitelů náboženství jako proces, který směřoval od prostého vnímání role učitele náboženství vztažené k žákům, ke škole, k církvi a k vlastní religiozitě (tedy v podstatě vůči obdobným oblastem, které popsal Mette) ke vnímání profesní identity jako kompetence, která se odvozuje od kompetencí, ke kterým má vést žáky. Jinými slovy, v popředí výzkumných otázek neležela snaha vystihnout, jak vnímají svou profesní identitu samotní učitelé náboženství, ale jak vyplývá z očekávání jmenovaných vztahových oblastí. Přitom upozorňuje na skutečnost, že i v německých zemích se učitelská profesionalita učitelů náboženství odlišuje od jiných oborů, protože i zde se učitelé náboženství dobrovolnicky angažují v jiných oblastech - např. v církvi, přičemž tato dvě pole nelze od sebe zcela oddělit jako dvě odlišné oblasti jejich angažmá.

Zatímco tedy podle Metteho spočívá profesionalita učitele náboženství ve zvládání role uprostřed napětí plynoucích z očekávání různých spoluaktérů náboženské výuky, u Schweitzera je profesionalita učitele náboženství vyjádřena jeho kompetencí utvářet kompetence žákovské. Charakter čistě učitelské profesionality učitelů náboženství Schweitzer zpochybňuje, když upozorňuje na činnosti, které s výukou náboženství souvisí, ale mají jiný než profesionální charakter. Tito autoři také naznačují, že v práci učitele náboženství nejde pouze o samotnou profesní identitu, ale také o další charakteristiky, jako je úkol být svědkem víry a tím, kdo zprostředkovává žákům víru nebo jim alespoň pomáhá, aby se v mnohotvárné multináboženské a světonázorové situaci současné společnosti orientovali a vnímali ji jako výzvu pro svůj život. V této jazykové oblasti tedy můžeme hovořit o učitelích náboženství jako o profesionálech, svědcích víry a misionářích, kteří svou kompetenci osvědčují především v tom, s jakým porozuměním a citem otevírají otázky náboženské víry žákům a studentům.

Na teoretické úrovni nelze toto chápání osobnosti učitele srovnat s výsledky relevantních českých studií či výzkumů, ačkoliv i dva výše uvedené ukazují na podobné kategorie, které se objevily i v analýze citovaných autorů $\mathrm{v}$ německy hovořící oblasti: vnímání učitelství náboženství jako profese, jako úkol plynoucí z pověření církve, jako činnost vycházející z osobní religiozity vykonávaná v určitých užších školních a širších společenských podmínkách. Což můžeme chápat jako výzvu pokusit se na základě jednoduchého kvalitativního šetření hledat u českých učitelů náboženství porozumění pro vlastní učitelskou identitu a diferencovaným způsobem ji popsat.

11 Srov. () RVP ZV (on-line), dostupné na http://www.nuv.cz/uploads/RVP_ZV_2017.pdf, citováno dne 3. 6. 2017.

12 Srov. Jarmila SKALKOVÁ, Za novou kvalitu vyučování, Brno: Paido, 1995. 


\section{Kvalitativní výzkum (ohnisková skupina)}

Metodologický rámec popisované kvalitativní sondy do charakteristiky osobností učitele náboženství byl zvolen $\mathrm{v}$ podobě analýzy a interpretace dat $\mathrm{z}$ diskuse $\mathrm{v}$ jedné ohniskové skupině, a to podle zásad D. L. Morgana. ${ }^{13}$

\section{Charakteristika ohniskové skupiny:}

O vytvoření ohniskové skupiny jsem požádala vikariátní koordinátory katechetické a pedagogické práce českobudějovické diecéze římskokatolické církve tak, že pro mě zprostředkovali kontakt s učiteli náboženství, které dobře znali ze své vlastní učitelské praxe. Vlastní ohniskovou skupinu tvořilo nakonec 11 členů, kteři se ovšem v rozporu s Morganovými empirickými pravidly navzájem více či méně znali. Úplnou anonymitu by totiž bylo vzhledem $\mathrm{k}$ malému počtu učitelů náboženství v českobudějovické diecézi obtížné zajistit. U jednotlivých členů uvádím jejich (vyfabulovaná) křestní jména a délku praxe:

$\begin{array}{lr}\text { Libuše } & \text { 26 let } \\ \text { Lucie } & 26 \text { let } \\ \text { Monika } & 15 \text { let } \\ \text { Václav } & 26 \text { let } \\ \text { Mirka } & 6 \text { let } \\ \text { Bára } & 25 \text { let } \\ \text { Lýdie } & 24 \text { let } \\ \text { Marta } & 1 \text { rok } \\ \text { Sofie } & 9 \text { let } \\ \text { Magda } & 20 \text { let } \\ \text { Helena } & 21 \text { let }\end{array}$

Z přehledu plyne, že pouze 1 účastnice patří mezi začínající učitele náboženství, pouze dvě mají praxi kratší než 10 let, pět praxi od 11 do 25 let a tři více než 25 let. Znamená to, že jde vesměs (až na jednu výjimku) o učitele, kteř́ se osvědčili v dlouholeté praxi, což mủže samožrejmě ovlivnit jejich pohled na vlastní profesi ve směru homogenního pohledu „starých praktikü“. Což validitu výzkumné sondy posouvá, ale nediskvalifikuje.

\section{Formulace otázek a průběh rozhovoru:}

Ve shodě s doporučením $\mathrm{D}$. L. Morgana jsem po vytvoření teoretického rámce pro kvalitativní sondu formulovala pět základních otázek, a to na velmi obecné úrovni, resp. zvolila jsem metodu „trychtýře“", tedy první velmi široce formulovaná otázka měla za úkol rozproudit diskusi. Zněla: 1. Proč jste se vůbec stali učiteli náboženství? Na ni navázaly tři konkrétnější otázky: 2 . Jak vnímáte sami sebe jako učitele?; 3. Co je pro vás v prostř̌edí školy jako pro učitele náboženství důležité?; 4. Jste spokojení učitelé náboženství? Poslední otázka se vztahovala (opět poněkud obecnějším způsobem, abych členům skupiny „nenutila“ svoje vlastní pohledy) $k$ církvi: 5. Co vás napadne, když se řekne slovo „církev“?

Samotný rozhovor trval 60 minut (protože odpadl úvodní čas potřebný ke vzájemnému seznámení se účastníků skupiny) ve společenské místnosti TF JU. Se souhlasem účastníků byl zazna- 
menán na diktafon s tím, že při zveřejnění jeho částí budou fabulována jejich křestní jména, aby byla zajištěna anonymita.

\subsection{Analýza získaných kategorií a jejich interpretace}

Kategorie popisuji a částečně interpretuji v logice otázek, které jsem pokládala skupině během rozhovoru.

\subsubsection{Vnější a vnitřní motivace k práci učitele náboženství - aneb „proč to má smysl“}

První - uváděcí otázka se snažila vyprovokovat co nejširší diskurs účastníků týkající se jejich motivace k práci učitele náboženství s tím, že jsem očekávala, že se spontánně dotknou i oblastí, které se k jejich učitelskému angažmá vážou (učitelská profese, škola a církev).

Učitelky spontánně vypovídaly o svých motivech k práci. Uváděly jak vnější bezprostřední impulsy, tak hlubokou vnitřní motivaci. Vnějším popudem byla nejčastěji na začátku jejich práce žádost kněze (Václav: ...pak ta konkrétní výzva pana děkana: Půjdeš učit do školy...") nebo potřeba kolegyně učitelky (Marta: Moje kamarádka, co učila náboženství, šla na mateřskou a řekla - půjdeš tam do školy, tam to je nepovinný kroužek...). Často to také byla potřeba věrících rodin ve farnosti (Helena: ...je to i na přání těch rodin $z$ farností, věrúcích rodin. Oni to od nás očekávají, oni očekávají od církve službu...). Vesměs tedy jde spíše o neformální situaci, kdy potřeba stát se učitelem náboženství vyrostla z potřeby církve vnímané jako společenství, jehož se oni cítí být součástí, nikoliv jako naplnění profesně zaměřeného studia. Důležitým vnějším motivem je setkání s dětmi a jejich světem, které „když jsem někdy strašně unavená, přinesou maličkost, drobnost, která člověka povzbudí a nabije k dalši práci" (Mirka).

Vnitřní motivaci popisuje většina členů skupiny jako emocionální prožitek, který racionálně interpretují (Monika: Mnozí z nás cití, že je to takový to poslání...). Svou práci nevnímají pouze jako profesi, ale jako poslání, povolání (Bára: Je to takový volání, aby se člověk rozhodl tou cestou se vydat...). Službu farnosti vnímají jako závazek. Zásadním vnitřním motivem je pro členy zkoumané skupiny vlastní niterné franklovsky pojaté zaměření na životní smysl, jak říká Marta: „Zjistila jsem..., že když doprovázím někoho na cestě k Bohu, tak jsem obohacená, mně to vlastně neustále baví, protože mně to obohacuje. "Pro to jsou schopni překonat i překážky - únavu, neporozumění či obavy z vlastní nedostačivosti. Setkávání se světem dětí se ve vnímání práce učitelů náboženství u členů zkoumané skupiny prohlubuje jejich zaměřením na víru dětí. To však začíná spontánní pozorností vưči existenciálním zkušenostem žáků (tak Lucie „prosmutnila“ s jednou dívenkou, které umřel dědeček, hodinu... ale to bylo úžasný, jak se ty děti chovaly, ta holčička plakala, tak jsme tam s ní byli a za dědečka se modlili, takhle to bylo..., takový krásný, nikdo se nesmál, dèti si vyprávěly, jak to prožívaly ony, když jim někdo umřel, a to se nenaplánuje...) přes evangelizační zaměření (Václav: To byla taková touha to duchovno předat, vlastně evangelium...), až po vzájemný dotek světa vlastní víry s vírou dětí. Tak má Václav někdy pocit, že: neučím já děti, ale děti mě... dotkl jsem se pravdy víry - ale dotkla se i mě - a najednou jsem si uvědomil - aha, tady je něco živýho... protože reagujou na nějaký téma a jsou schopny brát něco doopravdy... Nebo Marta, která je introvert a dělá jí problém o takových osobních věcech s Bohem mluvit, najednou začala během výuky náboženství o takových věcech mluvit. Vưbec důležitým vnitřním motivem zkoumané skupiny učitelů je to, že ovlivňují dětskou víru, byt’ přitom rozlišují mezi smyslem náboženské výuky ve škole a katechezí v církvi. Například Magda ř́ká: Já si nemũžu prostě stavět takovej vysokej levl, že ty děti budu prostě učit tak, že budou žit křestansky a dojdou do Božího království, protože jsem 
je něco naučila... To bych to musela zabalit. Ale pro mě je levl to, že ty děti mi na nějakej čas Pán Bůh svěř́, abych je doprovázela, a já bych si prála, aby oni si jednou vzpomněly, že... je Bưh na jejich straně, že je jako, že mu nejsou lhostejní, že o nich dobře ví, ne na mě aby vzpominaly, ale na Boha a aby na něj mély vzpomínku, že prostě je a že se na něj obrátí, když se budou třeba rozhodovat nebo prijdou zkouškami nebo i radostmi...".

\subsubsection{Učitel náboženství - hlasatel evangelia a laskavý průvodce „ve ztížených podmínkách“}

Druhá, třetí a čtvrtá otázka se týkaly vztahu členů skupiny k vlastní roli učitele náboženství v prostoru školy. V diskusi rozlišili učitelé především vnější znaky své učitelské role, ve kterých se shodují s ostatními učiteli. Týkaly se především samotné výuky a její administrace (Marta se musela třeba naučit zapisovat do elektronické tř́dní knihy a Lýdie dodává: Ale já se opravdu jako učitelka cítím jenom, když zapisuju do třídního výkazu, pišu hodnocení, do žákovských knižek, dávám testy a opravuju je...). Pečlivěji vymezili, v čem je jejich postavení ve srovnání s jinými učiteli horší. Především v organizačních podmínkách (tak Marta má děti od 1. do 5. třídy a Libuše říká: Učím na 4 školách, vždycky je to tak podobné, každý školní rok, někdy se to promění, já třeba učím na pěti školách během jednoho školního roku...) a ve finančním odměňování jejich práce (Libuše ř́ká: ...tu práci odvedu, ale jsem za to zaplacená - no to je otazník - určitě jen natolik, aby mohla vzniknout ta pracovně právní smlouva. Ted' mi někde zvedali plat - protože ze zákona musí být hodinová mzda asi 120,- Kč, tak mi zvedali, tak jsem se radovala, že mi zvedají plat, oni mi ho zvedli o pětikorunu, takže to je otázka...). Sami také vymezili specifické znaky role učitele náboženství. Jako kolegové vystupují občas vůči svým kolegům v roli experta na náboženské otázky (Marta: Najednou za mnou začaly chodit i jiné učitelky a chtěly nějakou radu...). Coby věŕící lidé se vnímají jako reprezentanti církve a hlasatelé evangelia. Magda upozorňuje, že to není prostě odučit si určitý počet hodin v té škole, ale nějakým zpưsobem reprezentovat nás věrící tam, kde člověk žije... abychom hlásali, když je potřeba hlásat nebo když jsme o to požádáni...).

Podstatně angažovaněji a spontánně nastolili členové skupiny problém jejich vztahu ke klimatu školy. Jeden směr uvažování popisoval tento vztah především jako vztah projevovaný ze strany vedení školy a kolegů směrem $\mathbf{k}$ učitelům náboženství. Zde vnímají jak vstřícnost (Bára např. takto: Tak mně ř́ká pan učitel, který má tu školu na starosti: děti, to je naše paní učitelka. A děti, už se zase těšite na ten vstup, jak paní učitelka přijde na Vánoce, nebo zase príijdte o Velikonocích... Už $s$ vámi počitáme. Prostě takhle mně uvádí.), občas si nejsou vůbec přijetím či nepřijetím ze strany školy jisti (Libuše za těch 25 let figurovala na jedný škole pouze dva roky na webových stránkách té školy v seznamu pedagogů. Díky jedné zástupkyni ředitele, která ji tam napsala, když po dvou letech odešla do důchodu..., tak to její jméno zmizelo), až k jistotě, že jako učitelé přijímáni nejsou (To si myslím, že není, že není rovnost vióči těm ostatním učitelưm tady... Lucie). Jako druhé téma vytvořili členové skupiny spojení s otázkou, jak oni sami ovlivňují klima školy. Lze je shrnout do kategorie harmonizující úkol v klimatu školy. Dobře to popisuje Lucie - jako roli laskavého důvěrníka: Ale zase si myslím, že máme jiný úkol, jako že neberu to jako na škodu, že prostě naše postavení je trochu jiný, když to trochu vyhrotím, že mým úkolem je být tam jako maminka... Dám př́klad, jednomu učitelovi umřela maminka a on mě přijal jako svoji maminku, hovořime spolu, máme takový vztah spolu. Nebo Libuše: To se mi líbí, že oni nás vnímají jako toho, kdo tam nese něco vyššího, jiného a je takovou houbou, která nasaje i to, co je třeba bolí...). Mohou se však s vedením školy dostat i do konfliktu, který ale lze vyřešit, když mají odvahu obhájit některá dětská práva - Magda: Jako učitelka náboženství jsem jednou vešla do takového kř́žku s panem ředitelem, protože jsme se dotkli toho, že se mi nelíbilo, jak učitelka na konci roku využila ten volný čas, kdy 
se už nemusí učit, který mi nepřipadal jako vhodný, a nevěděla bych to, kdyby mi to děti neřekly... A ty děti chtěly jít jinam a dělat něco jiného, ale bylo jim řečeno, že prostě v rámci demokracie musí zůstat, protože se hlasovalo...

Vůči spokojenosti s vlastní učitelskou rolí převážily u členů zkoumané skupiny především negativní pocity, a to z vlastní únavy a cizího nepřijetí (Václav: Já bych řek, že za těch x let už cítím pomèrně velkou únavu a hodně je člověk zklamanej z takovýho ňákýho neprijetí, že věci nejdou, jak by měly) i z vlastní nedostačivosti (Lucie: ... když to nejde, když se to seká, tak je člověk nespokojenej, když to nezvládá, nebo jo..."). Zvlášt diferencovaně vnímají nedocenění ve vlastní církvi, což formulují bud’ na obecné úrovni (Magda: Já bych řekla, že se necitím jako někdy podpořená a že je mi spíše líto ani ne tak jako že já nejsem podpořená, ale že není v̌̌eobecná jako v církvi zvyklost chválit, podpořit a poděkovat a povzbuzovat, motivovat..., protože se to bere automaticky jako služba...), nebo na zcela konkrétní úrovni (Marta: Trošku mně vadí, že i občas kněží nás vidí jako exoty. Proto tak jako trošku mám dojem, že pořád pro ně jsme prostě jako by lidi, o kterých si myslí, že jsou tak jako trošku podřadnější. A to mně vadí mnohem víc...). Poprvé se také objevuje negativní pocit z prožívání krize v církvi (Marta: Jak si uchovat víru... opravdu... Někdy se mi to tak jako vylučuje. Bưh a církev. Ježiś ji tvoři a tvoří ji lidé, tu církev. A ted' mám v sobě takovej...). Jeden identifikovaný pozitivní pocit popisuje vděčnost za to, že jim toto povolání naplnilo život smyslem (Marta: ...Takže spokojení jsme, v tom, co děláme a s těma dětma určitě jo...; Václav: Ale zase na druhou stranu cítím takovou hlubokou vdéčnost, že tohleto jsem mohl celou tu dobu a zatím můžu prostě dělat a dělám.), a znovu se vrátili ke konstatování, že je uspokojuje především smysluplnost práce při otevírání víry dětem školního věku.

\subsubsection{Učitel náboženství a církev - aneb jako doma $\mathrm{v}$ rodině: $\mathrm{v}$ radostech $\mathrm{i}$ strastech}

Na velmi obecně položenou otázku týkající se vztahu členů zkoumané skupiny k církvi reagovali účastníci diskursem, ve kterém rozlišili kategorii místní církev a obecně chápaná církev. Vedle toho položili do protikladu své vnímání církve jako rodiny nebo obecněji společenství a církve jako instituce. Vnímání církve analogické ke vnímání vlastní rodiny spojovali právě s místní církví (Libuše: Pro mě církev, a myslím tu místní, tu nejbližší, tak pro mě církev znamená rodinu.). Jednak ji vymezili staticky - jako hierarchicky uspořádané rodinné společenství (Magda: Dalo by se to vyjádrìt taky jako rodina, ale $v$ rodině vidím tu hierarchii toho otce a matky, ty autority, poslušnosti, ale někdy se v církvi ta hierarchie má tendenci možná trochu přeceňovat...), jednak dynamicky - jako průvodce jejich vlastního života (Libuše: Tak já jsem v podstatě z tý rodiny církve vyrostla, žejo, nejdřív úplně nejužší teda jakoby se svojí rodinou jsem chodila do té farnosti, pak v roli mládežníka, který tam nějak aktivně působil, pak pozvání ke studiu na teologické fakultě - pan vikář přišel do společenství mládeže a řekl: Tak podpořime fakultu tím, že vy tam pưjdete... Takže já jsem jako by byla vytažena z toho společenství, proto skutečně rodina. Nebo Sofie: Já jsem $v$ tom taky opravdu vyrostla. Já jsem odchovanec dětských poutí a diecézních, takže já viobec neznám žádnou dobu bez církve.). Pro členy skupiny je místní církev místo jak sdílené radosti, tak sdílené bolesti (Libuše: Já teda musím říct, že někdy je v církvi obrovská legrace. Jo, to kdybyste viděli někdy u nás na faře, tam je legrace, jo? Že to nemůžu říct... ale někdy opravdu přijdou chvíle, kdy jsou těžký věci, nebo nesete bolest s někým, a - jo, to tak prostě život nese, to je svět...). Církev vnímaná na obecné úrovni je zde chápána jako blízká rodině - jako společenství, kde má každý své místo (Bára: A v církvi je mi dobře. Takový prostředí, ve kterým člověk cítí, že tam má svoje místo, nebo že tam může žít jako - jak bych to prirovnala - prostě je mu tam dobře. Nebo Helena: Někde musíme mít zázemí, odkud vlastně vycházíme, a když to zázemí je dobrý, máme co předat zase dál do toho 
společenství...). Přitom opatrně naznačují i jevy spojené s krizí institucionální církve (Marta: ... ale já to beru tak trošku jako jinak, tak takový dva pohledy. Jednak to beru jako společenství fakt lidí, kteři věrí v jednu společnou věc a za tou prostě jdou, ale není to pro mě to samý jako instituce církve. Tam to vidím jinak. Moderátorka: Tam je ta krize? Marta: Jo, to je problém trošku). Jejich vztah k církvi se ovšem neodvíjí primárně ani od vztahu k církvi jako ke společenství lidí, ani jako $\mathrm{k}$ čistě lidské instituci. $\mathrm{V}$ diskusi se přiznávají $\mathrm{k}$ velmi intimnímu a niterném vztahu $\mathrm{k}$ Ježíši (Libuše: Já mám v kancelárí na stole takovej obrázek, možná někomu to připadá dětinské, ale je to Ježíš, na hlavě má trnovou korunu, stéká z ní krev, je zpocený, jde po cestě..., tak takhle si prèedstavuju církev. Že je plná bolesti, zranění, ale vevnitř je prostě v tom Ježišovi ta bolest. I darování se...). $\mathrm{V}$ okamžiku, kdy ve „svéc církvi narazí na nějaká negativa, je to pro ně výzva, aby svěřili tento problém Bohu (Libuše: Já si myslím, že tady někde je opravdu ta podstata kř́že. Naopak Marta vnímá jako bolestnou dobu, kdy nedokázala o svém prožívání krizových jevů $\mathrm{v}$ církvi, které se jí dotýkaly, hovořit: Já když jsem proživala nějaký ty bolesti v církvi, tak jsem o tom s Bohem prestala mluvit a dlouho to trvalo, než jsem si začala třeba zpětně uvědomovat, že to byla hrozná chyba.). Skrze svůj vlastní hluboký vztah k Ježíši i v situacích jeho a jejich utrpení rozumí církvi jako mystickému tělu Krista (Libuše: Kristus říká, že to je mystický tělo církve, církev jako... že je jeho tělo.). Tak - i přes, nebo právě pro negativa, která zažívají v instituci církve - dospívají paradoxně k lásce $\mathbf{k}$ církvi i v jejích nedostatcích a chybách (Monika: Proč ty to vlastně ještě děláš? Když kolikrát vidiš to neuznání, makáš tady, nemáš vedle sebe nikoho, kdo by ti pomoh', ale já jsem zjistila, že v těchhle těch krizových chvilích, kdy jsem utahaná, vycucaná, vyčerpaná, si uvědomuju, že já tu církev $v$ podstatě miluju.). Tento postoj jim potom dodává sílu, aby setrvali jak v církvi, tak v práci učitele náboženství, které chápou jako poslání dané Kristem a vyjádřené církví (Magda: Já bych ještě doplnila to, že právě proto, že třeba tady to tak trošku vyznívá, že církev jako instituce je v krizi, tak já jsem jako hrozně ráda, že učím náboženství... Člověk si uvědomuje, že v tý církvi od biskupa až po ty laiky jsou to jenom lidi, který mají i svoje omezení, svoje chyby. Já jsem ráda, že tam můžu pracovat a snažit se prostě ze všech svých sil dělat, aby byla krásná.).

\section{Diskuse}

Srovnáme-li výsledky této kvalitativní sondy do charakteristiky osobnosti českého učitele náboženství se dvěma citovanými německými autory, můžeme konstatovat následující:

Ačkoliv naše otázky sledovaly Metteho 3 kategorie vlivů na osobnost učitele náboženství pouze velmi obecně, členové zkoumané skupiny je sami v diskusi bud’ vytvořili (kategorie „klima školy“), nebo rozvinuli (vztah $\mathrm{k}$ roli učitele náboženství a vztah $\mathrm{k}$ církvi). V našem vzorku se sešli učitelé náboženství s praxí většinou delší než 10 let, je tedy možné, že jsme mimoděk zachytili typ vnímání profesní identity učitele náboženství, který své postoje osvědčuje delší praxí.

Výzkum ukázal na české specifikum pozornosti vůči žákům, kterou Mette pouze popsal, zatímco náš výzkum ji ukázal jako důležitý rozměr učitelské osobnosti, který naplňuje jeho práci smyslem. Naopak o tlaku školy na měřitelné výkony žákủ, o kterém hovoří jak Mette, tak Schweitzer, se naši učitelé náboženství vůbec nezmínili. Ve vztahu k samotné výuce rozlišují i čeští učitelé náboženství výuku ve škole a katechezi v církvi, ovšem definují ji na rozdíl od německých učitelů teologicky (ve škole jako evangelizaci).

Ve vztahu k vlastní religiozitě, na kterou ukazuje Mette jako na zdroj napětí mezi „žitým a vyučovaným náboženstvím“, neprojevili naši učitelé náboženství žádné napětí. Naopak výuka je logickým vyjádřením jejich žité religiozity.

Schweitzerovo upozornění na to, že vedle „hlavní - profesní identity odvozené od schopnosti 
učitele náboženství naplnit žákovské kompetence - existují i jiné charakteristiky učitelů náboženství (např. historie jejich osobní víry v sekularizující se společnosti), se projevilo v naší výzkumné sondě zcela opačně. Podstatnou charakteristikou zkoumaných učitelů náboženství byl jejich vlastní intenzivně prožívaný vztah k Bohu skrze Krista, ze kterého vyvozují jak svou církevní, tak profesní identitu.

Ve srovnání se závěry dvou českých kvantitativních výzkumů můžeme uzavřít, že aktuální kvalitativní sonda ukázala spíše na jistotu zkoumaných učitelů náboženství ve vlastní jádrové osobnostní dimenzi shodné se vztahem k Bohu skrze Krista, od které se odvíjí i jejich větší sebejistota na půdě školy, kde se nevnímají jako běžní učitelé, ale spíše jako laskaví průvodci dětí i dospělých. Nejsou si svojí rolí nejistí, spíše vyjadřují nespokojenost s okolnostmi, za kterých učí a občas i se svými vlastními hranicemi. Přičemž atmosféru škol nevnímají jako vysloveně odmítavou, jistotu v profesionalitě jim dodává vlastní teologicky popsaný evangelizační cíl výuky, který se opírá o pozornost vůči existenciálním zkušenostem dětí. Zdá se tedy, že vzhledem $\mathrm{k}$ dřívějším dvěma výzkumům mohlo dojít $\mathrm{k}$ posunu $\mathrm{v}$ sebehodnocení učitelů náboženství: svou profesionalitu odvozují od teologicky vnímaných cílů, které - spolu s reakcí na klima školy a na klima ve své vlastní církvi - postavili na živém a intenzivním vztahu k Bohu skrze Krista. Vưči škole a společnosti se neuzavírají, ale pronikají do ní prostřednictvím svých žáků, aby do ní vnesli křest’anské duchovní hodnoty.

\section{Závěr}

V úvodu jsem položila výzkumnou otázku: Jaké podstatné charakteristiky lze nalézt v osobnosti učitele náboženství v současné době v naší zemi?

$Z$ analýzy diskursu, který proběhl ve zkoumané skupině, lze v odpovědi skutečně vykreslit znaky určité osobnosti učitele náboženství. Podstatnou dimenzí, od které se se odvíjí jeho život jako celek, a tudíž i jeho život v církvi a v povolání učitele náboženství, je duchovní jádro jeho osobnosti, které je identické s jeho hluboce prožívaným niterným vztahem k Bohu skrze Krista. Je to prizma, skrze které vnímá a prožívá všechny oblasti svého života. Ve vztahu k práci učitele náboženství se potom tento postoj promítá do dvou základních oblastí: církev a škola.

Církev vnímá ambivalentně jednak jako rodinné společenství, ve kterém cítí analogii k rodinnému společenství a radostně ho prožívá, jednak jako instituci, která se ho čas od času dotkne svými morálními selháními. V takových chvílích čerpá ze svého hlubokého vztahu s Bohem v Ježíši Kristu a tato selhání prožívá jako bolest církve i svou vlastní, na kterou odpovídá vlastním upřímným angažmá. Ve škole vnímá svou roli podstatně hlouběji než pouze jako výuku odborného předmětu. Cítí se být laskavým průvodcem jak dětí ve viřre v hodinách náboženství, tak v životě kolegů, přijde-li s nimi do kontaktu. Z jeho základního postoje hluboké víry plyne, že spontánně vnímá svou učitelskou roli ve vztahu k cílům a obsahům výuky jako otevírání světa víry dětem, a to se smyslem pro jejich existenciální zkušenosti v současném světě. Ve své vlastní učitelské roli se však ze strany školního prostředí necítí zcela jistě, výuka jeho předmětu je v životě školy okrajová a organizačně obtížná, navíc sice nevnímá odpor vůči náboženství u vedení školy a kolegů, ale ne vždy si je jist svým přijetím.

Druhou důležitou dimenzí osobnosti učitele náboženství, jak vyplynula z tohoto výzkumu, je důraz na překážky, které zdolává učitel náboženství z pozice duchovního zaměření na hodnotu životního smyslu, jehož naplnění vidí v otevírání světa víry jak dětem, které přicházejí z věřících rodin, tak těm, pro které je výuka náboženství prvním setkáním s křest̉anskou vírou. 
Postoj hluboké víry, který v praxi naráží na řadu obtíží a překážek učitele náboženství ve vztahu ke škole a k církvi, je skutečnost, kterou je potřeba vzít vážně a rozvíjet ji i přii vzdělávání budoucích učitelů náboženství a katechetů. I to je však vzhledem ke specifičnosti profese učitele náboženství potřeba uskutečňovat $\mathrm{v}$ propojenosti osobnostního, profesionálního i duchovního rozvoje. Nabízí se různé modely mentoringu a supervize, které by mohly obsahovat již studijní programy $\mathrm{v}$ rámci vedení praxí na teologických fakultách, na něž by potom navázala nabídka supervizí i pro profesní a duchovní doprovázení učitelů náboženství. V českých podmínkách ho zatím nabízí v katolickém prostředí pouze ostravsko-opavská diecéze.

Samozřejmě, že výzkumná sonda $\mathrm{v}$ jedné ohniskové skupině má explorativní charakter a typ osobnosti učitele náboženství, na který ukázala, může být jedním z mnoha, které se v České republice vyskytují. Může být dán např. délkou praxe zúčastněných členů skupiny (jiné typy osobností nemusely překážky $\mathrm{v}$ církvi a ve školním prostředí řešit $\mathrm{z}$ duchovního jádra své osobnosti a přerušit práci a možná i život $\mathrm{v}$ církvi). $\mathrm{V}$ rozhovoru se členy skupiny však byl tento typ učitele náboženství jednoznačně identifikován.

\title{
Učitel náboženství - misionář a evangelizátor, ale i profesionál a expert. Především však následovník Krista
}

\begin{abstract}
Abstrakt
Cílem této studie je vymezit možné podstatné charakteristiky $v$ osobnosti českého učitele náboženství v současné době. Nejprve seznamuje čtenáře s empirickými výzkumy v ČR i v německy mluvících částech Evropy, a to jako teoretický rámec pro kvalitativní sondu do samotné charakteristiky osobnosti učitele náboženství. Sonda se opírá o analýzu dat v jedné ohniskové skupině učitelů náboženství českobudějovické diecéze. Výsledná interpretace dospívá k určitému typu učitele náboženství, který byl v rozhovoru identifikován. Tím otevírá možnost dalších empirických výzkumů.
\end{abstract}

Klíčová slova: osobnost učitele náboženství, ohnisková skupina, profesní identita učitele náboženství, identifikace učitele náboženství s církví

\section{Kontakt}

doc. PhDr. Ludmila Muchová, Ph.D.

Jihočeská univerzita v Českých Budějovicích

Teologická fakulta, Katedra pedagogiky

Kněžská 8, 37001 České Budějovice

muchova@tf.jcu.cz 